\title{
Transcriptome Analysis on Single Small Yellow Follicles Reveals That Wnt4 Is Involved in Chicken Follicle Selection
}

\author{
Yiya Wang, Qiuyue Chen, Zemin Liu, Xiaoli Guo, Yanzhi Du, Zhenjie Yuan, Miao Guo, \\ Li Kang, Yi Sun and Yunliang Jiang*
}

Shandong Provincial Key Laboratory of Animal Biotechnology and Disease Control and Prevention, College of Animal Science and Veterinary Medicine, Shandong Agricultural University, Tai'an, China

Ovarian follicle selection is an important process impacting the laying performance and fecundity of hens, and is regulated by follicle-stimulating hormone (FSH) through binding to its receptor [follicle-stimulating hormone receptor (FSHR)]. In laying hens, the small yellow follicle (6-8 $\mathrm{mm}$ in diameter) with the highest expression of FSHR will be recruited into the preovulatory hierarchy during ovarian follicle development. The study of molecular mechanism of chicken follicle selection is helpful for the identification of genes underlying egg-laying traits in chicken and other poultry species. Herein, the transcriptomes of chicken small yellow follicles differing in the mRNA expression of FSHR were compared, and a total of 17,993 genes were identified in 3 pairs of small yellow follicles. The Wnt signaling pathway was significantly enriched in the follicles with the greatest fold change in FSHR expression. In this pathway, the expression level of Wnt4 mRNA was significantly upregulated with a $\log _{2}$ (fold change) of 2.12. We further investigated the expression, function, and regulation of Wnt4 during chicken follicle selection and found that Wnt4 mRNA reached its peak in small yellow follicles; Wnt4 stimulated the proliferation of follicular granulosa cells (GCs), increased the expression of StAR and CYP11A1 mRNA in prehierarchical and hierarchical follicles, increased the expression of FSHR mRNA, and decreased the expression of anti-Müllerian hormone and OCLN mRNA. Treatment with FSH significantly increased Wnt4 expression in GCs. Moreover, Wnt4 facilitated the effects of FSH on the production of progesterone (P4) and the mRNA expression of steroidogenic enzyme genes in the GCs of hierarchical follicles, but inhibited the effects of FSH in the GCs of prehierarchical follicles. Collectively, these data suggest that Wnt4 plays an important role in chicken follicle selection by stimulating GC proliferation and steroidogenesis. This study provides a theoretical basis for improving the egg-laying performance of chicken and a reference for the elucidation of the molecular mechanism of follicular selection in mammals.

Keywords: chicken, follicle selection, follicle-stimulating hormone, granulosa cells, Wnt4

\section{INTRODUCTION}

The chicken ovary is a dynamic organ and a key component of the female reproductive system. Follicles of various sizes exist in the sexually mature chicken ovary and these can be broadly divided into prehierarchical follicles and hierarchical follicles (F1-F5) (1). During the laying period, follicles will be recruited into the preovulatory hierarchy from a cohort of small yellow follicles of 6-8 mm 
in diameter approximately once a day, a process termed follicle selection. The selected follicle will undergo rapid development from an F5 follicle to an F1 follicle until ovulation (2). This process is regulated by the hypothalamic-pituitary axis and the paracrine and autocrine factors from ovarian follicles (3). It is estimated that there are approximately 12,000 oocytes in a sexually mature hen, but only a few hundred of them are selected to mature and reach the ovulation stage (4); most small yellow follicles are not selected and undergo atresia $(5,6)$.

Follicle selection is indispensable in the reproductive process in female chickens, the hallmark of which is the proliferation and differentiation of granulosa cells (GCs). Several factors regulating the proliferation and differentiation of GCs have been reported, most of which belong to the transforming growth factor superfamily, for instance the group of bone morphogenetic proteins (BMPs) (7-9). In addition, anti-Müllerian hormone $(A M H)$ could decrease follicle-stimulating hormone (FSH) sensitivity and regulate follicle selection in mouse GCs (10), is highly expressed in chicken small follicles, prior to follicle selection (11). Occludin (OCLN) is expressed in GCs and affects the process of yolk transport around the time of chicken follicle selection (12). In chicken follicular GCs, the expression of steroidogenic acute regulatory protein $(S t A R)$ and cytochrome $\mathrm{P} 450$ family 11 subfamily A member 1 (CYP11A1) is prerequisite for progesterone synthesis, and is related to follicle selection (13). Among the multiple small yellow follicles isolated from a single chicken ovary, one typically exhibits a higher expression level of follicle-stimulating hormone receptor (FSHR) compared to the other follicles (14) and thereby acquires responsiveness to FSH, resulting in the proliferation and differentiation of GCs. Other inhibitory or non-activated signals in the prehierarchical follicles of laying hens may also exist to prevent GCs from responding to $\mathrm{FSH}$. However, the signal(s) that initiate FSH responsiveness within the selected follicles and the factors that trigger the differentiation of GCs in the process of follicle selection have not been clearly characterized.

Members of the Wnt family are secreted glycoproteins that were recently identified as regulators of ovarian function, acting as signaling molecules to modulate follicular responses to gonadotropins. Wnt proteins may act through $\beta$-catenindependent or $\beta$-catenin-independent pathways and their abnormal expression and activation may cause tumors (15-17). The $\beta$-catenin-dependent pathway is involved in the regulation of cell proliferation, cell fate determination, and embryonic induction $(18,19)$. Wnt signaling pathways are critical for ovarian development and essential for normal follicle development (20). The number of oocytes was found to be decreased in Wnt4 (Wnt family member 4)-null female mice (21). Wnt4 regulates the vascular boundary of the ovary in mice by regulating follistatin and maintains the survival of germ cells (22), and Wnt4 conditional knockout mice displayed low fertility and blocked antral follicle development (20). In rodents, Wnt4 was found to be specifically expressed in the follicular GCs and corpora lutea, and its expression level could be regulated by an ovulatory dose of hCG (21). In chickens, Wnt4 was found to be highly expressed in the shell gland and isthmus of the oviduct and regulated by estrogen (23), but its role in follicular selection was not investigated.
To uncover the molecular mechanisms of follicle selection in hens, we identified the differentially expressed genes (DEGs) in small yellow follicles differing in FSHR expression by using Illumina RNA deep sequencing. A total of 1,999 DEGs were identified from the RNA-seq data. Among them, the mRNA expression level of Wnt4 increased along with the upregulation of FSHR mRNA. Given the important role of FSH signaling in follicle selection, we hypothesized that the expression of Wnt4 is likely regulated by FSH and Wnt4 plays some roles in this process. In this study, we analyzed the expression dynamics of Wnt4 in different-sized follicles, its effect on GC proliferation and differentiation and the effect of FSH on its expression in GCs of prehierarchical and hierarchical follicles. These results may help us to further understand the molecular mechanisms of follicle selection in hens.

\section{MATERIALS AND METHODS}

\section{Animals and Samples}

Several sexually mature (30 weeks old) Jining Bairi hens, an indigenous chicken breed that is well known for early sexual maturity at around 100 days, were randomly selected from the local research farm affiliated with Shandong Agricultural University. All chickens had free access to water and feed. The chickens were housed in separate cages with a daily light period of $14 \mathrm{~h}$ and the laying events were monitored to determine the regular laying sequence. Three hens in the middle of a laying sequence were sacrificed by decapitation immediately after oviposition. All of the small yellow follicles $(6-8 \mathrm{~mm}$ in diameter) were collected and stored in liquid nitrogen for RNA isolation. All of the animal experiments were approved by the Institutional Animal Care and Use Ethics Committee of Shandong Agricultural University and performed in accordance with the "Guidelines for Experimental Animals" of the Ministry of Science and Technology of China.

\section{RNA Isolation and RNA-Seq Library Preparation}

Total RNA was extracted from all of the small yellow follicles (6-8 $\mathrm{mm}$ ) using TRIzol reagent (Invitrogen) according to the manufacturer's instructions. RNA purification, cDNA synthesis, and RNA-seq were performed at Biomarker Technologies Co., Ltd. (Beijing, China). Enrichment of eukaryotic mRNA was performed using a NEBNext Poly(A) mRNA Magnetic Isolation Module (NEB, E7490), and the rRNA and concentrated prokaryotic mRNA were removed using a MICROBExpress Bacterial mRNA Enrichment Kit (Invitrogen, AM1905). mRNA was used as a template to construct the library. The qualified library was clustered on an Illumina cBot and finally sequenced using an Illumina HiSeq 2500. Prior to analysis, the low-quality reads and rRNA sequences were removed, and the clean reads were mapped to the chicken genome. The structure and expression of DEGs were analyzed and the functional annotation of the genes was accomplished by comparison with the reference genome: Gallus gallus (assembly Gallus_gallus-5.0). 


\section{Protein-Protein Interaction (PPI) Networks}

Protein-protein interaction networks were constructed based on the information from STRING version 10.0, which permits the critical assessment and integration of PPIs, including both direct (physical) and indirect (functional) associations. Credible interactions (combined_score $\geq 0.4$ ) were accepted for further network analysis using CytoScape.

\section{Cell Culture}

The hierarchical follicles and all of the small yellow follicles were isolated from egg-laying hens and placed in phosphate-buffered saline (PBS). The small yellow follicles were treated with $0.1 \%$ collagenase II (MP Biomedicals, Santa Ana, CA, USA) at $37^{\circ} \mathrm{C}$ for $10 \mathrm{~min}$ to obtain the GCs. The yolks of the follicles were removed carefully with ophthalmic forceps and the GCs were isolated from the hierarchical follicles and then dispersed by treatment with $0.25 \%$ trypsin-EDTA (Gibco) at $37^{\circ} \mathrm{C}$ for $15 \mathrm{~min}$ with gentle oscillation in a centrifuge tube. After centrifugation, the GCs were suspended in culture medium (M199 with 10\% fetal bovine serum and $1 \%$ penicillin/streptomycin), and subsequently seeded in 24 -well culture plates at a density of $1 \times 10^{5} /$ well. The number of cells was detected using Trypan blue. Cells were cultured at $38^{\circ} \mathrm{C}$ in an atmosphere of water-saturated $5 \% \mathrm{CO}_{2}$ for $24 \mathrm{~h}$.

\section{Plasmid Construction and Cell Transfection}

The coding DNA sequence region of Wnt4 was cloned from chicken cDNA by PCR. The amplified fragment spanned the region between the transcription initiation site and the termination codon. PCR products were cloned into the pUSEamp vector (Millipore) to generate the overexpression plasmid. All of the primers are listed in Table S1 in Supplementary Material. The shRNA of Wnt4 was synthesized by Shanghai GenePharma Co., Ltd. (Shanghai, China), and the target sequences are listed in Table S2 in Supplementary Material. GCs were plated on 24-well plates for the transient transfection experiments. The cells were transfected with the overexpression vector and shRNA (800 ng/ well) using Lipofectamine LTX and Plus Reagent (Invitrogen). Six hours after transfection, recombinant FSH was added. Twentyfour hours after transfection, the cells were lysed for RNA and protein extraction.

\section{Real-time Quantitative PCR}

The total RNA was extracted from all of the follicles using TRIzol reagent (Invitrogen), and the total RNA from the cultured GCs was isolated using a MicroElute Total RNA Kit (Omega). The quality of the total RNA samples was tested by gel electrophoresis and spectrophotometry. The cDNA was synthesized using a PrimeScript RT Reagent Kit with a gDNA Eraser (TaKaRa, Dalian, China). The total reaction volume was $20 \mu \mathrm{L}$, containing $1 \mu \mathrm{g}$ total RNA, $1 \mu \mathrm{L}$ oligo(dT) $)_{18}$ primer, $1 \mu \mathrm{L}$ of PrimeScript RT Enzyme Mix I, $4 \mu \mathrm{L}$ of $5 \times$ PrimeScript Buffer, and RNase-free $\mathrm{ddH}_{2} \mathrm{O}$. The program was $37^{\circ} \mathrm{C}$ for $15 \mathrm{~min}$ and $85^{\circ} \mathrm{C}$ for $5 \mathrm{~s}$. Real-time quantitative PCR was performed on an MX3000p system (Stratagene, La Jolla, CA, USA). The reaction system contained $1.5 \mu \mathrm{L}$ cDNA, $7 \mu \mathrm{L}$ of $2 \times$ SYBR Premix Ex Taq II (TaKaRa, Dalian, China),
$0.3 \mu \mathrm{L}$ of $50 \times$ Rox Reference Dye II, $0.3 \mu \mathrm{L}$ of each of the forward and reverse primers, and RNase-free $\mathrm{ddH}_{2} \mathrm{O}$. The program was $95^{\circ} \mathrm{C}$ for $30 \mathrm{~s}$, and $40 \mathrm{cycles}$ of $95^{\circ} \mathrm{C}$ for $5 \mathrm{~s}, 60^{\circ} \mathrm{C}$ for $30 \mathrm{~s}$, and $72^{\circ} \mathrm{C}$ for $20 \mathrm{~s}$. Melting curves were used to confirm the specificity of each product, and the PCR efficiency was determined by analysis of two-fold serial dilutions of the cDNA. The PCR efficiency was close to $100 \%$, allowing the use of the $2^{-\Delta \Delta \mathrm{CT}}$ method for the calculation of relative gene expression (24). The mRNA expression of the genes FSHR, Wnt4, StAR, CYP11A1, AMH, OCLN, and so on was quantitatively analyzed by this method. All of the primers are listed in Table S1 in Supplementary Material.

\section{Western Blotting}

The total protein content was isolated from different follicles using Cell Lysis Reagent (Fermentas) and the protein concentration was determined using the bicinchoninic acid assay. Goat anti-mouse Wnt4 polyclonal antibody was purchased from Santa Cruz Biotechnology, Inc. Equal amounts of protein were separated by $10 \%$ sodium dodecyl sulfate gel electrophoresis under denaturing and non-reducing conditions and then transferred to polyvinylidene fluoride (PVDF) membranes. The PVDF membranes were first blocked, then incubated $\left(1 \mathrm{~h}, 37^{\circ} \mathrm{C}\right)$ with the Wnt4 antibody diluted (1:500) in a $5 \%$ bovine serum albumin (BSA)/PBS solution. After washing in phosphate-buffered saline with Tween 20, the blots were incubated with horseradishperoxidase-conjugated goat anti-mouse immunoglobulin G antibody (1:1,000; Abcam) in a 5\% BSA/PBS solution. The signals were visualized using a 3,3'-diaminobenzidine (DAB) substrate kit (Tiangen).

\section{ELISA}

The Wnt4 levels in the medium were detected using a Chicken Wingless-Type MMTV Integration Site Family Member 4 (Wnt4) ELISA Kit (Shanghai Enzyme-linked Biotechnology Co., Ltd.). The culture media of four kinds of cells [GCs and theca cells (TCs) of hierarchical follicles, and GCs and TCs of prehierarchical follicles] were collected and centrifuged at 3,000 rpm for $30 \mathrm{~min}$ to remove debris. The Wnt4 level was then determined according to the manufacturer's instructions. The optical density of every well was tested at $450 \mathrm{~nm}$ using an ELx808 Absorbance Reader (BioTek, Winooski, VT, USA). The sample concentrations were calculated according to the mean absorbance.

\section{Cell Proliferation Assay}

The proliferation of GCs was detected using an Enhanced Cell Counting Kit-8 Assay Kit (Beyotime, Beijing, China). Approximately $6 \times 10^{3}$ cells were seeded in every well of a 96-well plate. The cells were transfected with the pUSEamp-Wnt4 plasmid and shRNA of Wnt4 when the cells reached 60\% confluence. At $0,24,48$, and $72 \mathrm{~h}$ after transfection, $100 \mu \mathrm{L}$ of medium with $10 \mu \mathrm{L}$ of CCK 8 was added to each well, and then the plates were incubated for a further $2 \mathrm{~h}$ at $38^{\circ} \mathrm{C}$. The absorbance was evaluated using an ELx808 Absorbance Reader at $450 \mathrm{~nm}$.

\section{Statistical Analyses}

All data are presented as the mean \pm SEM. The differences between different groups were determined by one-way ANOVA followed 
by Duncan's test using the SPSS software (SPSS Inc., Chicago, IL, USA). The differences between groups were considered significantly different when $p<0.05$.

\section{RESULTS}

\section{Sequencing Results Summary}

RNA-seq was used to compare the transcriptomes of six small yellow follicles, which are referred to here as T1, T2, T3, T4, T5, and $\mathrm{T} 6$ ( $\mathrm{T} 1$ and $\mathrm{T} 4, \mathrm{~T} 2$ and $\mathrm{T} 5$, and $\mathrm{T} 3$ and $\mathrm{T} 6$ were derived from three different laying hens). The mRNA expression levels of FSHR for follicles T1, T4, T2, T5, T3, and T6 were $1.08 \pm 0.01,5.75 \pm 0.27$, $1.00 \pm 0.06,1.25 \pm 0.16,1.04 \pm 0.19$, and $1.08 \pm 0.02$, respectively, as determined by qRT-PCR, and the high-throughput RNA-seq generated $45.39,44.14,44.09,43.81,43.48$, and 42.73 million raw reads, respectively, for the six follicles. Of these, $75.13-78.40 \%$ could be mapped to the chicken genome, and more than $98 \%$ of the reads were unique (Table 1 ). The sequencing reads

TABLE 1 | Summary of the RNA-seq results for 6-8 $\mathrm{mm}$ follicles.

\begin{tabular}{lccc}
\hline Follicles & Total reads & Mapped reads & Unique mapped reads \\
\hline T1 & $45,386,126$ & $34,531,801(76.08 \%)$ & $33,958,795(98.34 \%)$ \\
T2 & $44,094,300$ & $33,394,769(75.73 \%)$ & $32,776,351(98.15 \%)$ \\
T3 & $43,484,988$ & $33,045,809(75.99 \%)$ & $32,479,464(98.29 \%)$ \\
T4 & $44,143,998$ & $34,610,174(78.40 \%)$ & $33,947,343(98.08 \%)$ \\
T5 & $43,809,214$ & $32,912,529(75.13 \%)$ & $32,292,304(98.12 \%)$ \\
T6 & $42,730,428$ & $32,314,323(75.62 \%)$ & $31,706,047(98.12 \%)$ \\
\hline
\end{tabular}

were submitted to NCBI's GEO under the accession number GSE100673.

A total of 17,993 genes were examined for the six follicles, and the expression of all of these genes is listed in Table S3 in Supplementary Material. In the process of screening for DEGs between groups, a fold change $\geq 2$ and false discovery rate (FDR) $<0.01$ were used as the criteria. In the T1 vs. T4 group, 1,968 DEGs were detected, including 561 upregulated genes and 1,407 downregulated genes. In the T2 vs. T5 group, 289 DEGs were detected, including 104 upregulated genes and 185 downregulated genes. In the T3 vs. T6 group, 590 DEGs were detected, including 225 upregulated genes and 365 downregulated genes (Table S4 in Supplementary Material). To validate the RNA-seq data, some DEGs were chosen and quantified by qRT-PCR. The results showed that the mRNA levels of these genes were similar to the sequencing data (Table 2).

\section{Functional Analysis of DEGs}

In order to explore the key candidate genes related to follicle development, a network of the DEGs was obtained using STRING PPI network analysis (Figure 1); all of the genes are listed in Table S5 in Supplementary Material. Some of the genes, for instance Smad2, Wnt4, and FSHR, were found to play vital roles in the network.

In the three groups, with the increase in FSHR expression, the number of DEGs increased. To further explore the biological functions of these genes, we performed KEGG analysis and GO assignments of the DEGs, and the corresponding

TABLE 2 | Relative mRNA expression of ten selected genes from the three groups for comparison between the RNA-seq and qRT-PCR results.

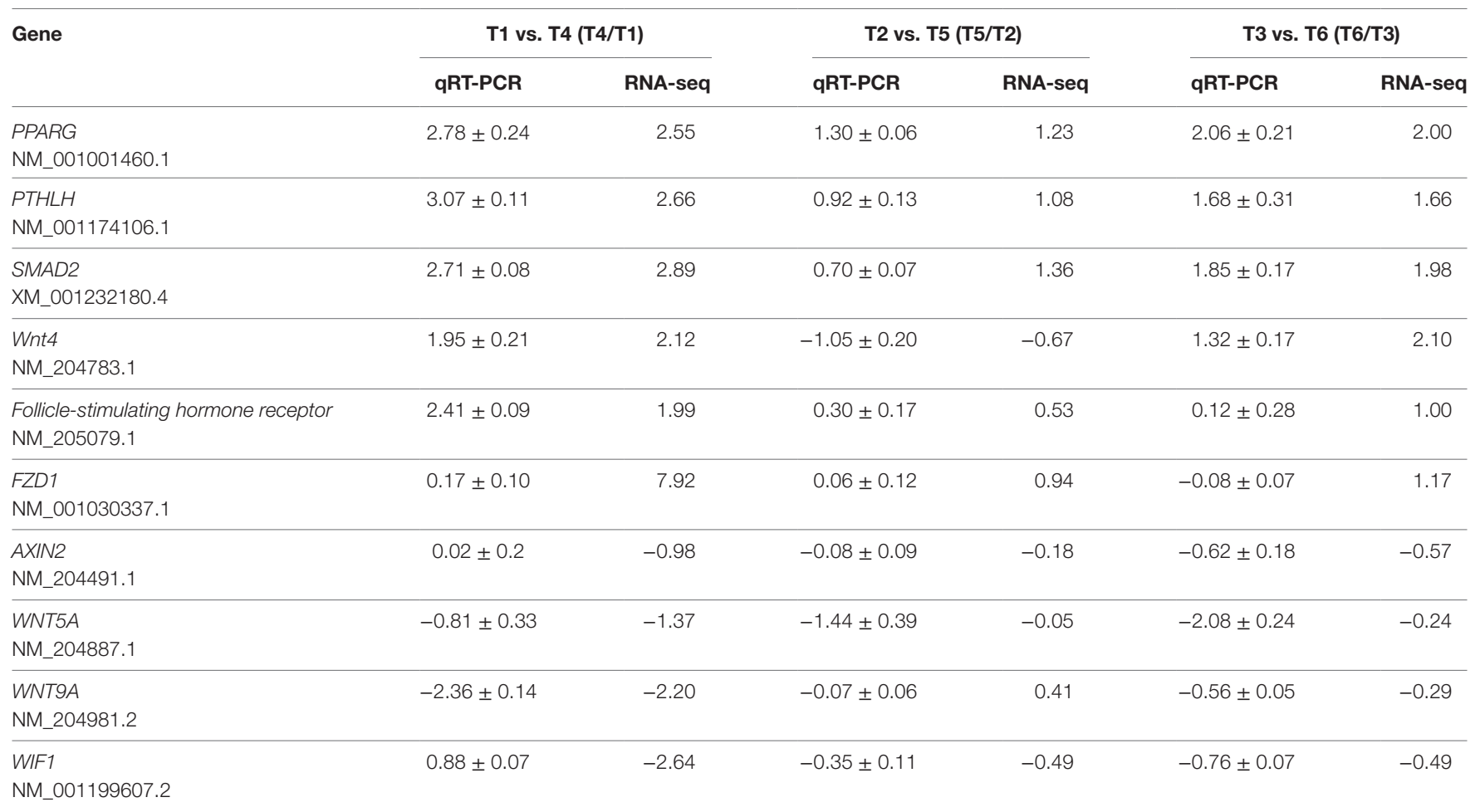

qRT-PCR data are shown as mean of fold change \pm SEM. RNA-seq data are shown as mean of fold change (false discovery rate). 


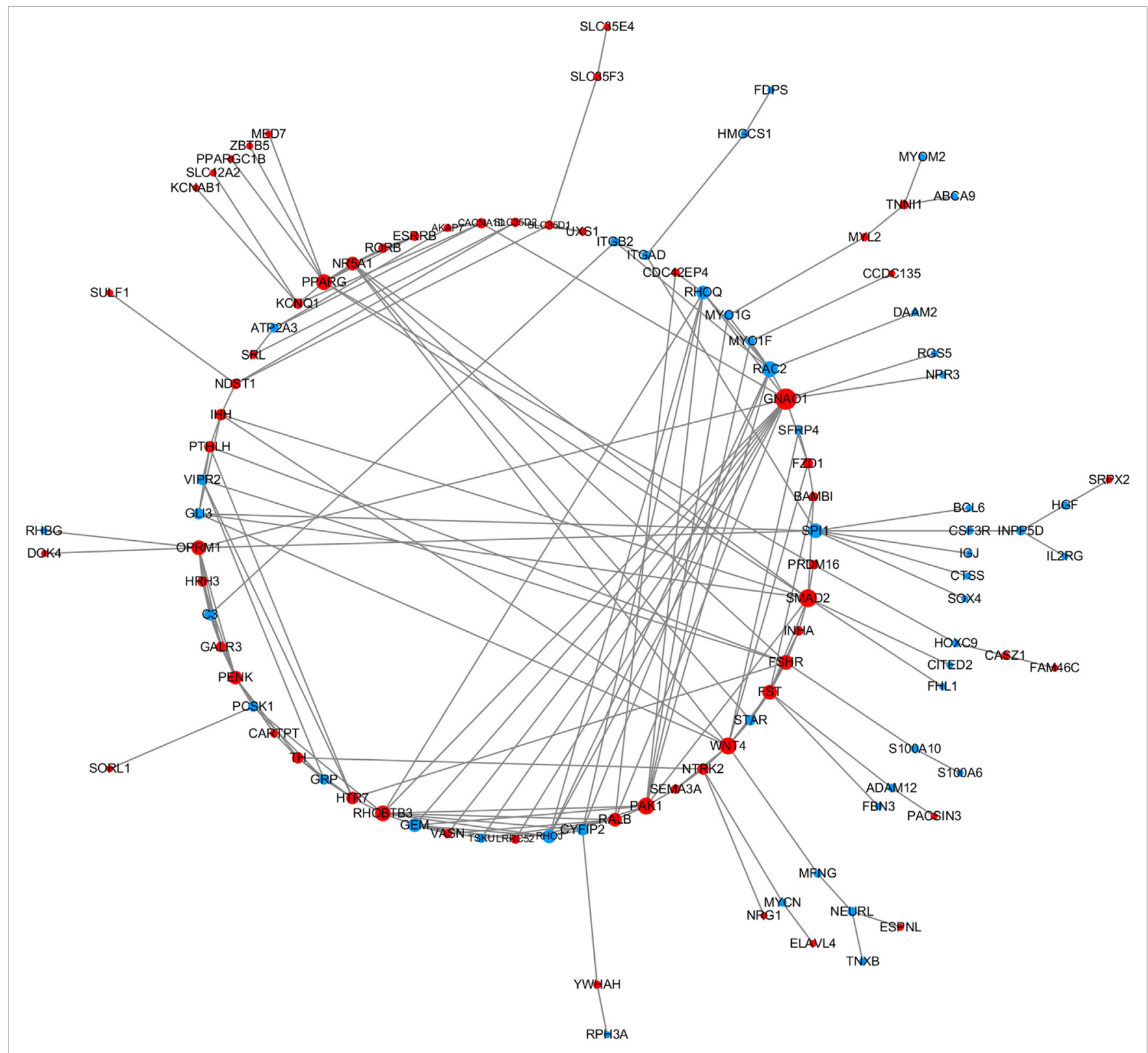

FIGURE 1 | The protein-protein interaction network of the differentially expressed genes (DEGs). STRING was used to analyze the DEGs. The network nodes represent the genes shown in Table S5 in Supplementary Material (red and blue indicate upregulated and downregulated genes, respectively) and the lines represent interactions between genes.

information is listed in Tables S6 and S7 in Supplementary Material. The significantly enriched KEGG pathways of the three groups are shown in Table 3. In the T1 vs. T4 group, the Wnt signal pathway was significantly enriched, and the DEGs of the Wnt signal pathway are shown in Table 4. In the follicle with the highest expression level of FSHR, the expression level of Wnt4 was also significantly higher than the follicle with the lowest expression level of FSHR, with a $\log _{2}$ (fold change) of 2.12. We hypothesized that Wnt4 may play an important role in follicle selection and development, and therefore subsequently analyzed its function.

\section{Expression Characteristics of Wnt4 in Follicles}

Wnt4 was expressed in both the prehierarchical and hierarchical follicles, but the expression level in the prehierarchical follicles was significantly higher than that in the hierarchical follicles $(p<0.01)$. The Wnt4 expression level was found to be highest in the small yellow follicles $(6-8 \mathrm{~mm})$, then declined significantly in the F5 follicles $(p<0.01)$, and this downward trend continued until $\mathrm{F} 1$, then slightly increased in the postovulatory follicles (POFs) (Figure 2A). On the protein level, Wnt4 was highly expressed in the prehierarchical, F5, and F3 follicles, but declined 
TABLE 3 | Significantly enriched pathways.

\begin{tabular}{|c|c|c|}
\hline Pathway & $p$ Value & $\begin{array}{l}\text { UniGene } \\
\text { number }\end{array}$ \\
\hline \multicolumn{3}{|l|}{ T1 vs. T4 } \\
\hline Focal adhesion & 0 & 76 \\
\hline ECM-receptor interaction & $6.80 \mathrm{E}-13$ & 46 \\
\hline Cytokine-cytokine receptor interaction & $1.42 \mathrm{E}-09$ & 52 \\
\hline Cell adhesion molecules & 1.13E-07 & 33 \\
\hline TGF- $\beta$ signaling pathway & 0.000100699 & 21 \\
\hline Vascular smooth muscle contraction & 0.000111614 & 27 \\
\hline Amebiasis & 0.000368349 & 6 \\
\hline Melanogenesis & 0.000937358 & 22 \\
\hline Calcium signaling pathway & 0.003524408 & 33 \\
\hline Adherens junction & 0.004793109 & 17 \\
\hline MAPK signaling pathway & 0.005027368 & 43 \\
\hline Regulation of actin cytoskeleton & 0.006272819 & 36 \\
\hline Wnt signaling pathway & 0.006320051 & 27 \\
\hline Gap junction & 0.0071262 & 18 \\
\hline Steroid hormone biosynthesis & 0.009703041 & 9 \\
\hline Arrhythmogenic right ventricular cardiomyopathy & 0.013001616 & 5 \\
\hline VEGF signaling pathway & 0.01314305 & 15 \\
\hline Gastric acid secretion & 0.013974998 & 2 \\
\hline Intestinal immune network for IgA production & 0.024274613 & 8 \\
\hline Phosphatidylinositol signaling system & 0.028484703 & 16 \\
\hline \multicolumn{3}{|l|}{ T2 vs. T5 } \\
\hline PPAR signaling pathway & 0.007689374 & 4 \\
\hline Focal adhesion & 0.016837656 & 7 \\
\hline Progesterone-mediated oocyte maturation & 0.019698938 & 4 \\
\hline Dorsoventral axis formation & 0.03060988 & 2 \\
\hline Cardiac muscle contraction & 0.035262584 & 3 \\
\hline Lipoic acid metabolism & 0.039079049 & 1 \\
\hline Oocyte meiosis & 0.040688919 & 4 \\
\hline Adipocytokine signaling pathway & 0.047671798 & 3 \\
\hline Wnt signaling pathway & 0.848944256 & 1 \\
\hline \multicolumn{3}{|l|}{ T3 vs. T6 } \\
\hline Steroid biosynthesis & 0.0003184 & 5 \\
\hline Phagosome & 0.0042824 & 12 \\
\hline NOD-like receptor signaling pathway & 0.005853671 & 6 \\
\hline Terpenoid backbone biosynthesis & 0.017505751 & 3 \\
\hline DNA replication & 0.031551297 & 4 \\
\hline $\begin{array}{l}\text { Glycosaminoglycan biosynthesis - chondroitin } \\
\text { sulfate }\end{array}$ & 0.048837386 & 3 \\
\hline Wnt signaling pathway & 0.441815127 & 6 \\
\hline
\end{tabular}

significantly in the F1 follicles and POFs $(p<0.01)$ (Figure 2B). In both the hierarchical and prehierarchical follicles, the Wnt4 mRNA and protein levels were significantly higher in the GCs than in the TCs $(p<0.01)$ (Figure 3).

\section{Effect of Wnt4 on Steroidogenic Enzyme Gene Expression in GCs}

To determine the effect of Wnt4 on steroidogenic enzyme gene expression, GCs were treated with Wnt4 overexpression vectors and shRNA. In pre-GCs, the expression levels of StAR $(p<0.01)$ and CYP11A1 $(p \leq 0.001)$ mRNA were significantly increased as a result of Wnt4 overexpression (Figure 4A). In GCs, the expression levels of StAR $(p \leq 0.001)$ and CYP11A1 $(p \leq 0.05)$ were also significantly increased (Figure 4B). The mRNA expression levels of StAR $(p<0.05)$ were significantly reduced in pre-GCs and GCs
TABLE 4 | Differentially expressed genes of Wnt signal pathway in the T1 vs. T4 group.

\begin{tabular}{|c|c|c|c|}
\hline Gene & $\begin{array}{c}\text { False } \\
\text { discovery rate }\end{array}$ & $\begin{array}{l}\log _{2}(\text { fold } \\
\text { change) }\end{array}$ & $\begin{array}{c}\text { Up- or } \\
\text { downregulated }\end{array}$ \\
\hline$F Z D 1, F Z-1, c F Z-1$ & 0 & 7.916035833 & Up \\
\hline SMAD2, MADH2 & 0 & 2.887762211 & Up \\
\hline Wnt4 & $6.66 \mathrm{E}-16$ & 2.115271676 & Up \\
\hline WIF1 & 0.000361044 & 1.145351015 & Up \\
\hline Similar to strabismus & 0.006074629 & -1.050277449 & Down \\
\hline DAAM2 & 0.003280038 & -1.089648489 & Down \\
\hline PLCB1 & 0.008015936 & -1.104548086 & Down \\
\hline NFATC2 & 0.003303788 & -1.106378948 & Down \\
\hline SFRP4 & 0.00029446 & -1.158226013 & Down \\
\hline SFRP1, CSFRP1 & $4.51 \mathrm{E}-05$ & -1.237170155 & Down \\
\hline $\begin{array}{l}\text { Similar to disheveled, dsh } \\
\text { homolog } 1\end{array}$ & $8.21 \mathrm{E}-05$ & -1.261713034 & Down \\
\hline WNT5A & 0.000213247 & -1.366774461 & Down \\
\hline PRKCA & $2.29 \mathrm{E}-07$ & -1.526470318 & Down \\
\hline CAMK2D & 1.17E-06 & -1.531255044 & Down \\
\hline $\begin{array}{l}\text { Similar to protein kinase } \mathrm{C} \\
\text { beta type }\end{array}$ & $4.18 \mathrm{E}-05$ & -1.552007291 & Down \\
\hline PRKCA & 1.69E-07 & -1.566220886 & Down \\
\hline $\begin{array}{l}\text { Hypothetical protein } \\
\text { LOC100230090 }\end{array}$ & 0.000575417 & -1.731836055 & Down \\
\hline$F Z D 3, F Z-3, c F Z-3$ & 3.83E-05 & -1.873285715 & Down \\
\hline PRICKLE2 & $3.48 \mathrm{E}-11$ & -2.005821446 & Down \\
\hline $\begin{array}{l}\text { Similar to HMG-box } \\
\text { transcription factor TCF-3 }\end{array}$ & $7.66 \mathrm{E}-10$ & -2.014370297 & Down \\
\hline$L E F 1, L E F-1$ & $1.78 \mathrm{E}-09$ & -2.026783917 & Down \\
\hline NFATC1 & $1.01 \mathrm{E}-05$ & -2.057215317 & Down \\
\hline$F Z D 2, c F z-2$ & $1.51 \mathrm{E}-12$ & -2.073360036 & Down \\
\hline WNT5B & $8.38 \mathrm{E}-12$ & -2.098749215 & Down \\
\hline WNT9A, WNT-14 & $5.76 \mathrm{E}-12$ & -2.200244472 & Down \\
\hline SFRP5 & $4.11 \mathrm{E}-13$ & -2.606370027 & Down \\
\hline$F Z D 7, F z-7, c F z-7$ & $1.36 \mathrm{E}-11$ & -3.265319335 & Down \\
\hline
\end{tabular}

after knockdown of Wnt4 expression, whereas those of CYP11A1 were not significantly reduced (Figure 5).

\section{Effect of Wnt4 on the Proliferation of GCs}

As Wnt4 was highly expressed in GCs, we speculated that it is likely involved in GC proliferation in fast-growing follicles. Consequently, GCs were transfected with the overexpression vector pUSEamp-Wnt4 and the shRNA of Wnt4 to examine the effect of Wnt4 on their proliferation. We found that the overexpression of Wnt4 significantly stimulated the proliferation of GCs $(p<0.05)$ (Figure 6A). Conversely, when the Wnt4 expression level was knocked down, the proliferation of GCs significantly decreased $(p<0.01)$ (Figure 6B).

\section{Involvement of Wnt4 in Follicle Selection}

Follicle-stimulating hormone receptor, $A M H$, and OCLN are the key regulators of follicle selection, and so we determined the expression levels of these genes upon changing the expression level of Wnt4. In the prehierarchical GCs, the expression level of the mRNA for FSHR $(p<0.01)$ was significantly increased by the overexpression of Wnt4, and the expression levels of $A M H(p<0.05)$ and OCLN $(p<0.01)$ were simultaneously 

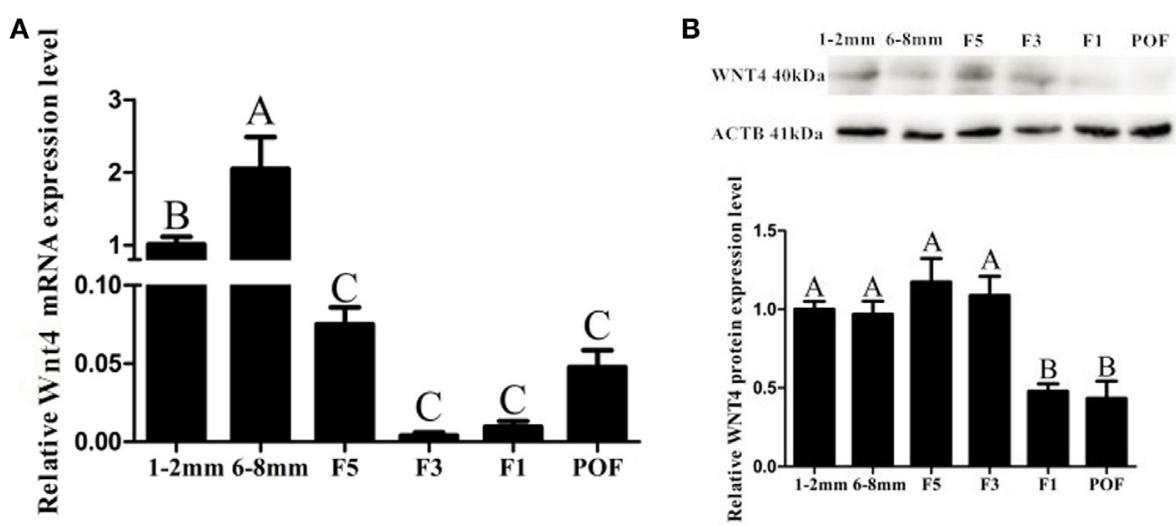

FIGURE 2 | Expression of Wnt4 in follicles at different developmental stages from 30-week-old hens. (A) Expression levels of Wnt4 mRNA in 1-2 mm follicles, 6-8 mm follicles (small yellow follicles), the fifth largest follicles (F5), the third largest follicles (F3), the largest follicles (F1), and the newly postovulatory follicles (POFs). (B) Expression levels of Wnt4 protein in the various follicles. Data are presented as the mean \pm SEM from at least three independent experiments. Bars with different letters are significantly different $\left({ }^{\mathrm{ABC}} p<0.01\right)$.
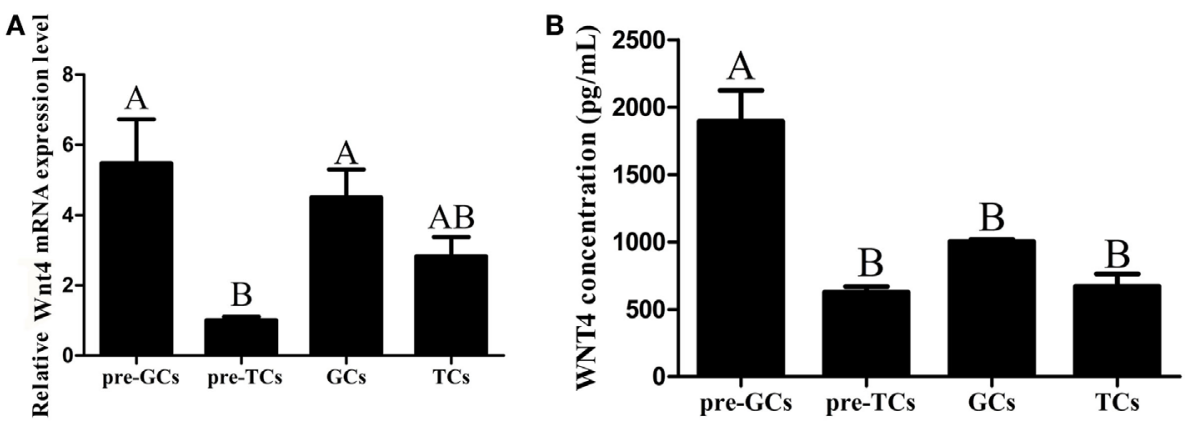

FIGURE 3 | Expression of Wnt4 in granulosa cells (GCs) and theca cells (TCs). (A) mRNA expression of chicken Wnt4 in the GCs and TCs of hierarchical follicles and the GCs (pre-GCs) and theca cells (pre-TCs) of prehierarchical follicles. (B) Protein expression of chicken Wnt4 in GCs, TCs, pre-GCs, and pre-TCs ( ${ }^{\mathrm{ABC}} p<0.01$ ).

decreased (Figure 7A). Furthermore, the expression levels of $A M H(p<0.05)$ and OCLN $(p<0.01)$ mRNA were increased in prehierarchical follicle GCs treated with the shRNA of Wnt4, and the level of FSHR mRNA $(p<0.01)$ was simultaneously decreased (Figure 7B).

\section{Effect of FSH on Wnt4 Expression}

Follicle-stimulating hormone treatment at $5 \mathrm{ng} / \mathrm{mL}$ increased the expression of Wnt4 at both the mRNA $(p<0.05)$ and protein $(p<0.01)$ levels in the GCs of prehierarchical follicles (Figure 8A). In hierarchical follicles, with the increase of FSH concentration, the expression level of Wnt4 gradually increased $(p<0.01)$. Although a slight upward trend seems to occur, no significant difference of Wnt4 protein levels was observed in the hierarchical follicles (Figure 8B).

\section{Suppression of the Effects of FSH on Steroidogenic Enzyme Gene Expression in GCs of Prehierarchical Follicles by Wnt4}

As the Wnt4 expression level changed during follicle development and was affected by the concentration of FSH, we further focused on the function of Wnt4 in follicular selection and development. In the GCs of prehierarchical follicles, FSH significantly increased the mRNA expression level of StAR and CYP11A1 $(p<0.01)$, although it had no significant stimulatory effect on progesterone and no effect on the expression of FSHR. When GCs were treated with a combination of FSH and Wnt4, Wnt4 suppressed the effect of FSH on the StAR and CYP11A1 mRNA levels $(p<0.01)$ (Figure 9A).

\section{Facilitation of the Effects of FSH on Steroid Secretion and Steroidogenic Enzyme Gene Expression in GCs of Hierarchical Follicles by Wnt4}

In the GCs of hierarchical follicles, FSH significantly increased the mRNA expression level of FSHR and the concentration of progesterone $(p<0.01)$, but not those of StAR and CYP11A1. When GCs were treated with a combination of FSH and Wnt4, progesterone secretion and steroidogenic gene expression were both significantly increased $(p<0.01$ ) to levels exceeding those observed upon treatment with FSH or Wnt4 alone (Figure 9B). 


\section{A}
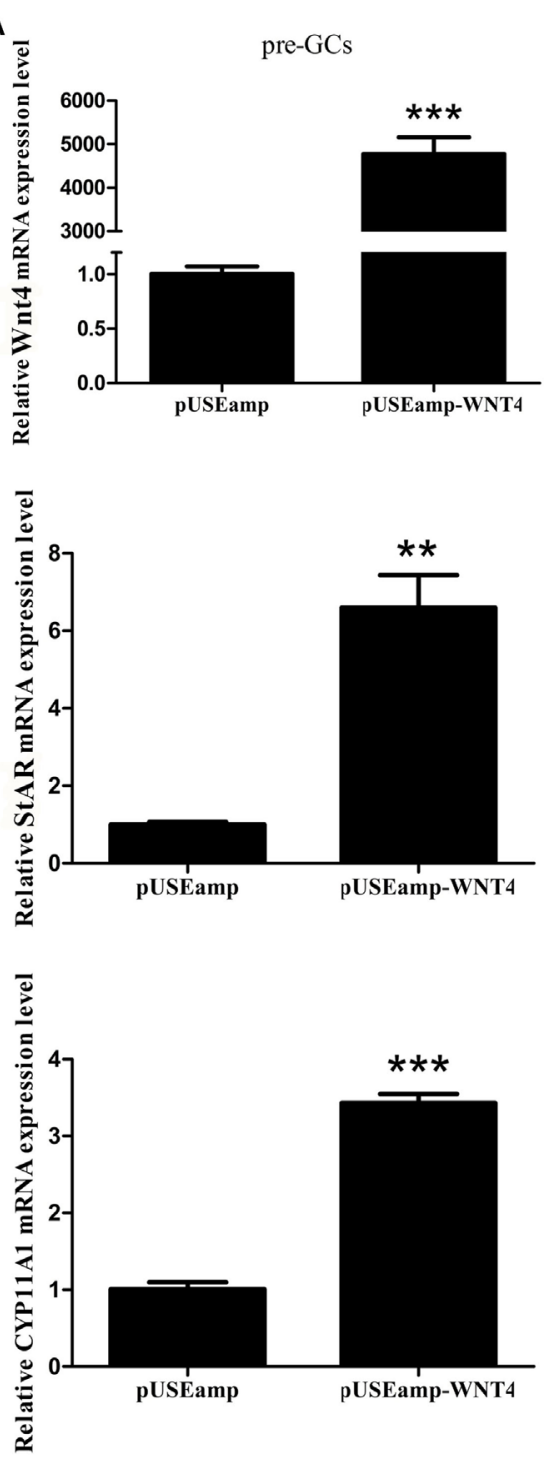
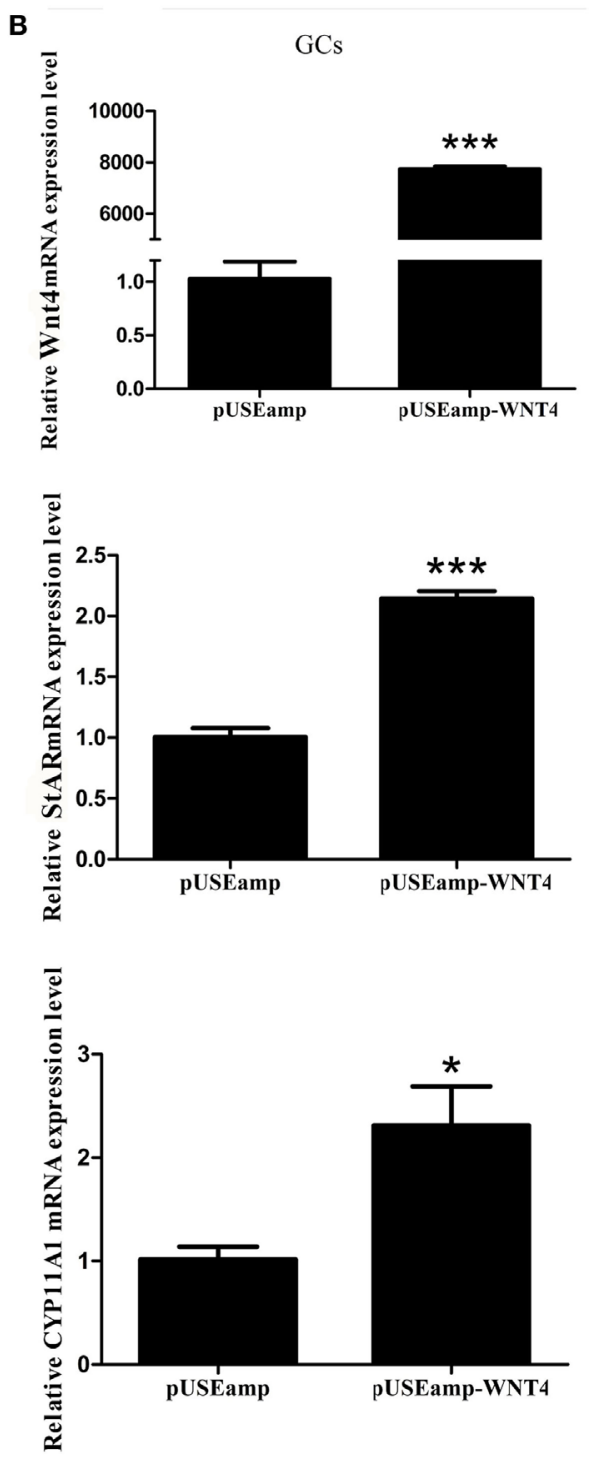

FIGURE $4 \mid$ Effect of Wnt4 overexpression on the expression of StAR and CYP11A1 in (A) pre-GCs and (B) GCs of chicken follicles $\left({ }^{\star} p<0.05\right.$, ${ }^{\star \star} p<0.01$, $\left.{ }^{\star \star *} p \leq 0.001\right)$.

\section{DISCUSSION}

Follicular selection and development are important for egg production and laying performance in the poultry industry. Understanding gene expression patterns during the follicle selection period is crucial to understanding the laying mechanism and improving the laying performance of hens. Recent studies have shown that all of the small yellow follicles isolated from the same ovary in a laying hen can express FSHR and respond to stimulation by FSH (25-27), and one of them contains significantly higher FSHR mRNA expression levels than the others, and this follicle will be selected to the hierarchical follicles (14). In this study, follicles with different FSHR expression levels displayed different transcriptomes and the Wnt signal pathway was significantly enriched along with the higher expression of the FSHR gene. Consequently, we investigated the DEGs during the period of follicle selection and the role of Wnt4 in follicle selection and development.

Follicle selection, growth, and muturation depend upon many endocrine, paracrine, and autocrine signals. The selection of one follicle from a large pool of small yellow follicles to form a hierarchical follicle requires the participation of signal molecules. The evidence has shown that during the period of follicle selection, the TGF- $\beta$ signaling pathway is involved in initiating follicle selection $(7,8,11) . B M P 15$ may promote follicle selection in hens; with the production of $B M P 15$, the oocyte regulates the surrounding somatic cells during follicle selection (9). Moreover, $B M P 6$ was found to promote FSHR and $A M H$ expression in the 

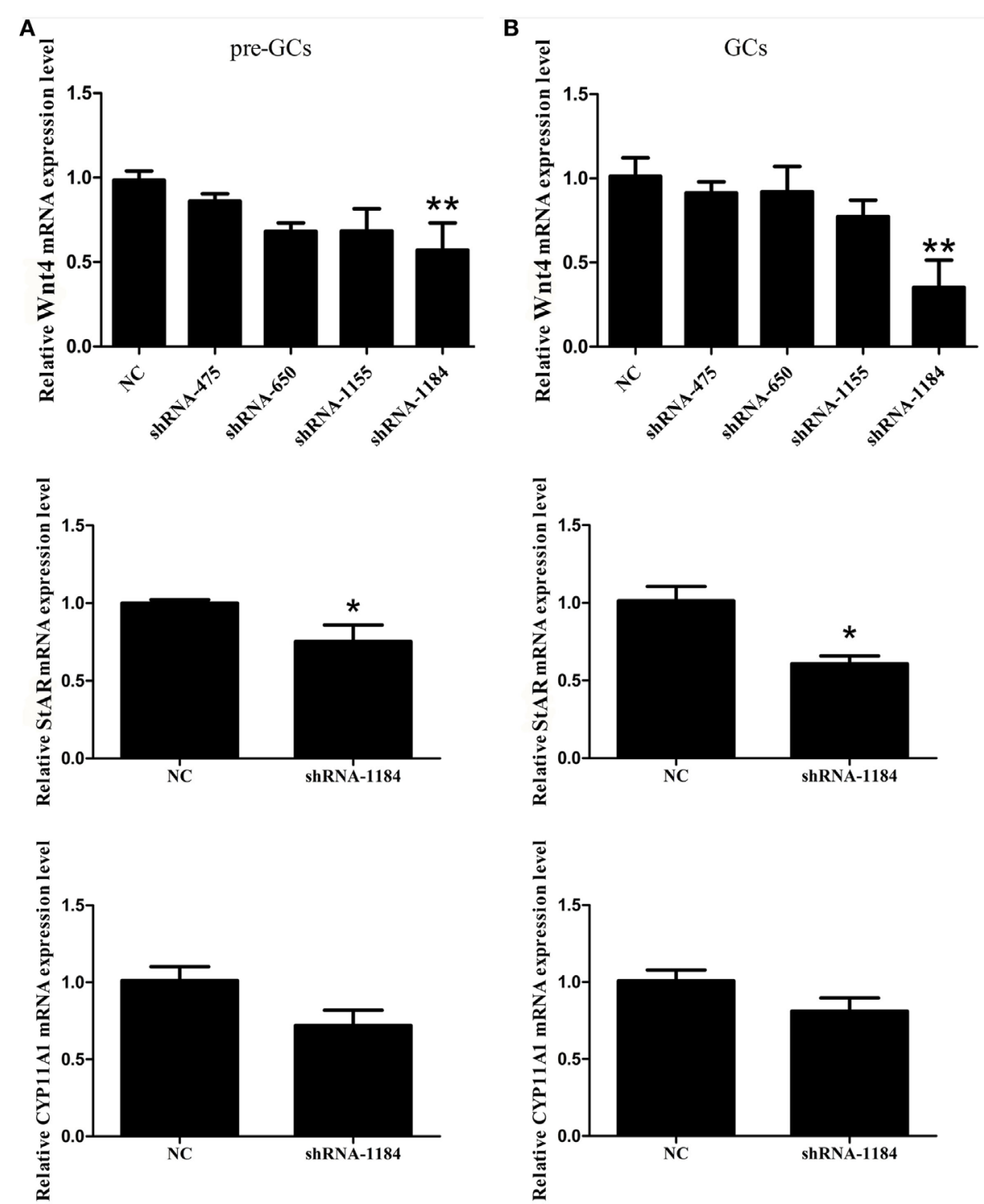

FIGURE 5 | Effect of Wnt4 knockdown on the expression of StAR and CYP11A1 in (A) pre-GCs and (B) GCs of chicken follicles $\left({ }^{*} p<0.05,{ }^{* *} p<0.01\right)$.

GCs from prehierarchical follicles in hens, and FSH signaling suppresses $A M H$ expression and initiates the differentiation of GCs within the selected follicles (3). In our previous study, the gene expression profiles of small white follicles, F1, and POF were obtained by RNA-seq (28). In this study, DEGs were identified by the comparison of small yellow follicles expressing significantly different levels of FSHR from the same laying hens, to explore the molecular mechanisms of follicle selection. Hundreds of DEGs and tens of signal pathways, including the TGF- $\beta$ and Wnt signaling pathways, were revealed. The expression of Wnt4 was significantly increased in the small yellow follicles of laying hens with the highest expression of FSHR, suggesting that Wnt4 is likely to be involved in follicle selection and changes in its expression level may be related to the effect of FSH. Therefore, the role of Wnt4 in follicle selection is subsequently investigated.
Previous studies have unveiled the contributions of members of the Wnt family to follicular development and steroid production in rodents $(29,30)$. Wht4 was expressed in small avian follicles $(0.5-2 \mathrm{~mm})$ and was downregulated during early follicular development (31). Wnt4 is known for regulating differentiation of the embryonic ovary (32) and is highly expressed in small mammalian follicles. In this study, Wnt4 was found to be expressed in follicles of all sizes in hens. Wnt4 was more highly expressed in the small yellow follicles than in the 1-2 mm follicles, and in chicken follicles, the expression of Wnt4 was significantly higher in the GCs than in the TCs, which is in accordance with the results obtained in rats, mice, and humans (33-36). In mice, Wnt4 was expressed in GCs throughout follicle development (21).

When chicken GCs were treated with the overexpression vector and shRNA of Wnt4, the expression levels of CYP11A1 and 

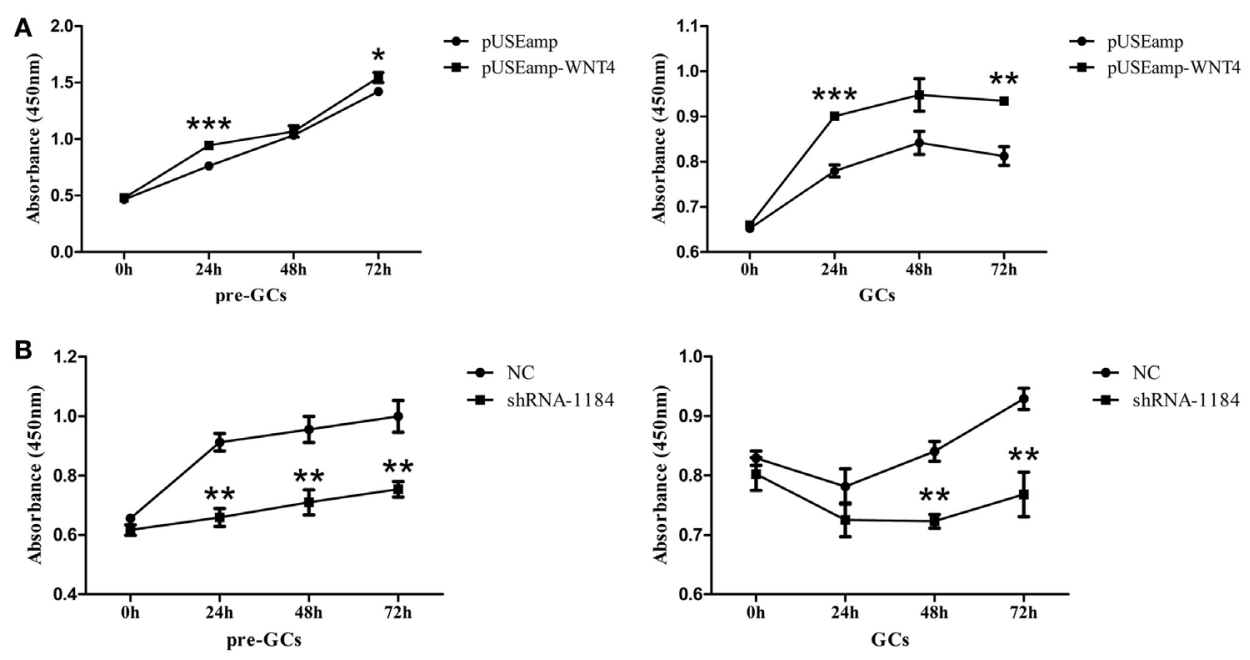

FIGURE 6 | Effect of Wnt4 on chicken granulosa cell (GC) proliferation. (A) Overexpression of Wnt4 in GCs stimulated cell proliferation, as determined by the CCK8 method. (B) Knockdown of Wnt4 in GCs inhibited cell proliferation, as determined by the CCK8 method. $\left({ }^{\star} p<0.05,{ }^{* *} p<0.01,{ }^{* \star *} p \leq 0.001\right)$.
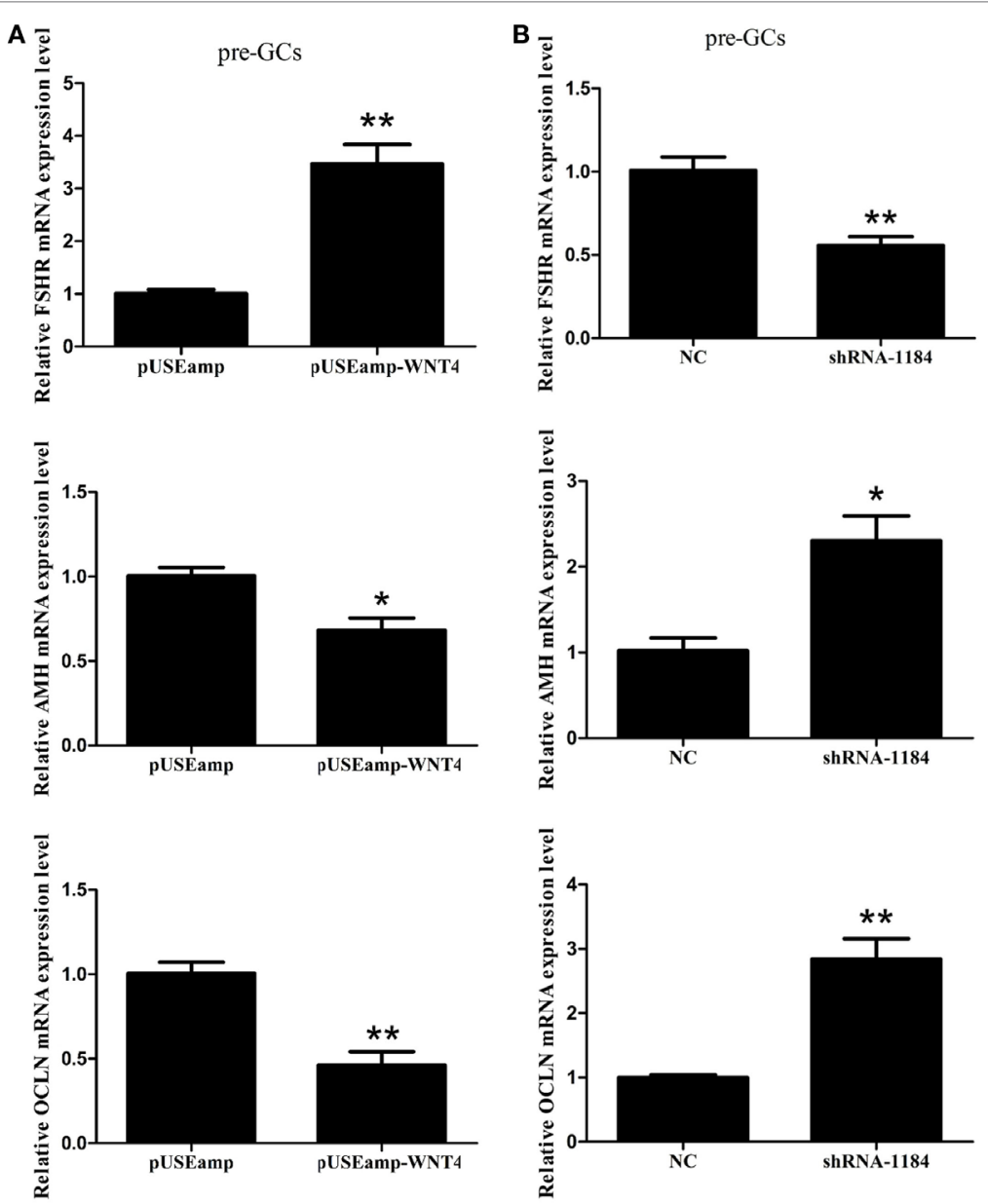

FIGURE 7 | Effect of Wht4 on follicle-stimulating hormone receptor (FSHR), anti-Müllerian hormone (AMH), and OCLN expression in prehierarchical follicle granulosa cells (GCs). (A) Overexpression of Wnt4 increased the expression level of FSHR, but decreased those of AMH and OCLN. (B) Knockdown of Wnt4 decreased the expression level of FSHR, but increased those of $A M H$ and OCLN $\left({ }^{\star} p<0.05,{ }^{\star \star} p<0.01\right)$. 

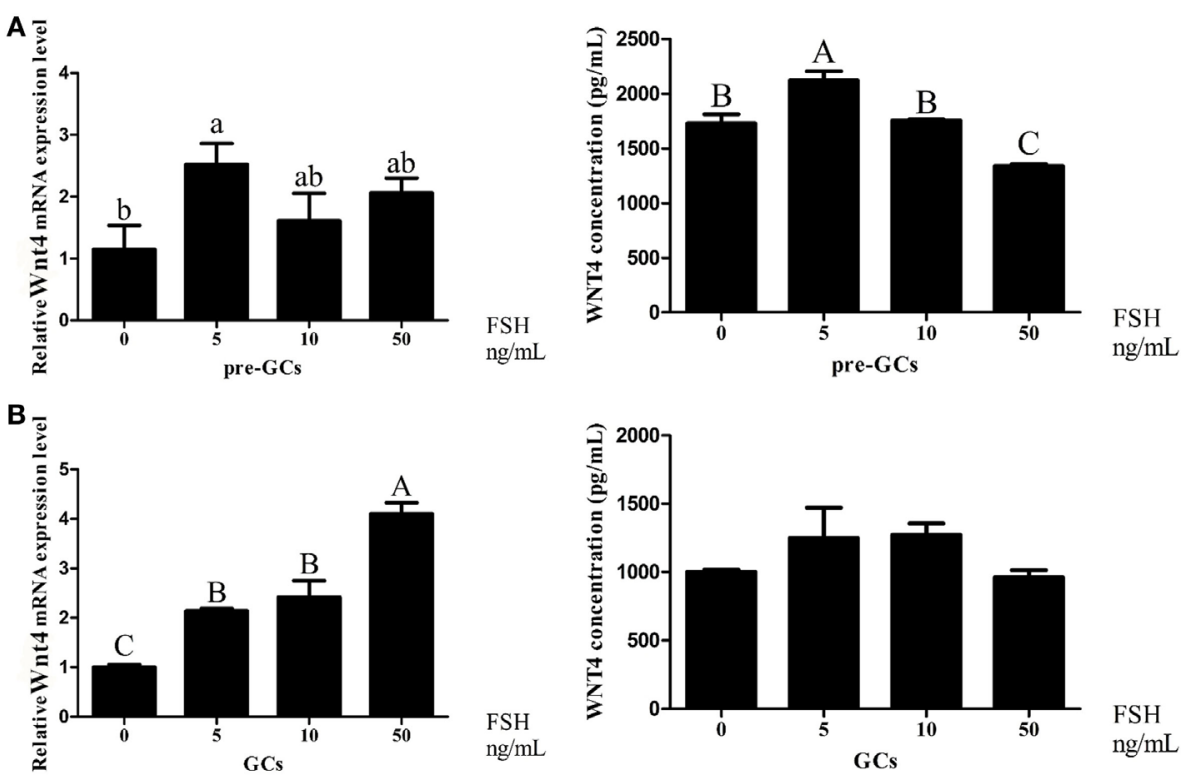

FIGURE 8 | Effects of follicle-stimulating hormone (FSH) treatment on the Wnt4 mRNA and protein levels in the granulosa cells (GCs) of ovarian follicles. Various doses of FSH $(0,5,10$, and $50 \mathrm{ng} / \mathrm{mL})$ were tested. (A) Effect of FSH on Wnt4 in the GCs of prehierarchical follicles. (B) Effect of FSH on Wnt4 in the GCs of hierarchical follicles. All data are presented as the mean \pm SEM. $\left({ }^{\text {abc }} p<0.05\right.$; $\left.{ }^{A B C} p<0.01\right)$.

StAR were greatly altered. Chicken GC differentiation involves the responsiveness of GC layers to $\mathrm{FSH}$, which is measured by their capacity to produce steroids such as StAR and progesterone (37). The overexpression of Wnt4 in mice GCs resulted in the increased expression of CYP11A1 and StAR. Wnt4-null mice displayed lower expression levels of CYP11A1 and StAR compared to the controls (20). These results are consistent with ours, suggesting that Wnt4 likely stimulated GC differentiation. Moreover, under the same conditions, we found that the overexpression of Wnt4 stimulated the cell proliferation of GCs from both prehierarchical and hierarchical follicles, whereas the knockdown of Wnt4 expression produced the opposite effect, suggesting that Wnt4 could stimulate GC proliferation.

Both the viability of chicken prehierarchical follicles and the cell differentiation associated with the selection of a single small yellow follicle per day into the hierarchical follicles depend on FSH and the expression level of FSHR in GCs. FSHR is expressed in GCs at all stages of prehierarchical follicles, but only one small yellow follicle can express the highest FSHR mRNA level, and this follicle will be recruited to become a hierarchical follicle (14). $A M H$ is a member of the TGF- $\beta$ family, and its mRNA expression level declines as the follicle size decreases; it is most abundant in 1-2 mm follicles (11) and significantly decreases during the period of follicle selection (2). Tight junction proteins including $O C L N$ are present in GCs. It has been suggested that OCLN could regulate access of the yolk to the oocyte surface around the time of follicle selection (12). The expression levels of FSHR, $A M H$, and OCLN changed after follicle selection $(2,11,12)$. We speculated that Wnt4 could participate in follicle selection by regulating the expression levels of these genes. In the present study, Wnt4 increased the expression level of FSHR, but decreased the mRNA levels of $A M H$ and OCLN. Furthermore, when the expression level of Wnt4 declined, the expression of these genes increased. The effects of Wnt4 on the expression of FSHR, AMH, and OCLN suggest that Wnt4 plays a role in follicle selection in hens.

Evidence suggests that the expression of Wnt family genes is hormonally regulated in rodent and bovine ovaries. In rodent ovaries, Wnt4 expression is detected in response to human chorionic gonadotropin (21), and in bovine GCs, upregulation of Wnt2 mRNA expression was elevated when treated with FSH (38). During the period of chicken follicle selection, the small yellow follicle expressing the highest FSHR level acquires optimal responsiveness to FSH (1). As for the regulation of Wnt4 expression by FSH in chicken follicles, we found that Wnt4 expression is elevated in GCs following FSH stimulation. We further analyzed the combinatorial effect of Wnt4 and FSH on chicken prehierarchical and hierarchical follicles. In the GCs of hierarchical follicles, Wnt4 can strengthen the influence of FSH; however, in prehierarchical follicles, Wnt4 has an inhibitory effect on the function of FSH. Several studies have suggested that FSH and Wnt signaling pathways may work together to influence steroid production in the postnatal ovary, as in the case of humans, rats, and cows (39-41). Johnson supposed that the responsiveness to FSH was suppressed in prehierarchical follicles, but in hierarchical follicles, some signals are activated, the follicles become responsive to FSH (1), and the responsiveness to FSH is initiated by increasing cAMP production in GCs (3). In the GCs of prehierarchical follicles, there may exist an inhibitory or non-activated signal, and the GCs cannot respond to FSH (1). The difference in the effect of Wnt4 on the action of FSH may suggest an interaction of Wnt4 signaling and FSH signaling in hierarchical follicles, but in prehierarchical follicles, as the small 

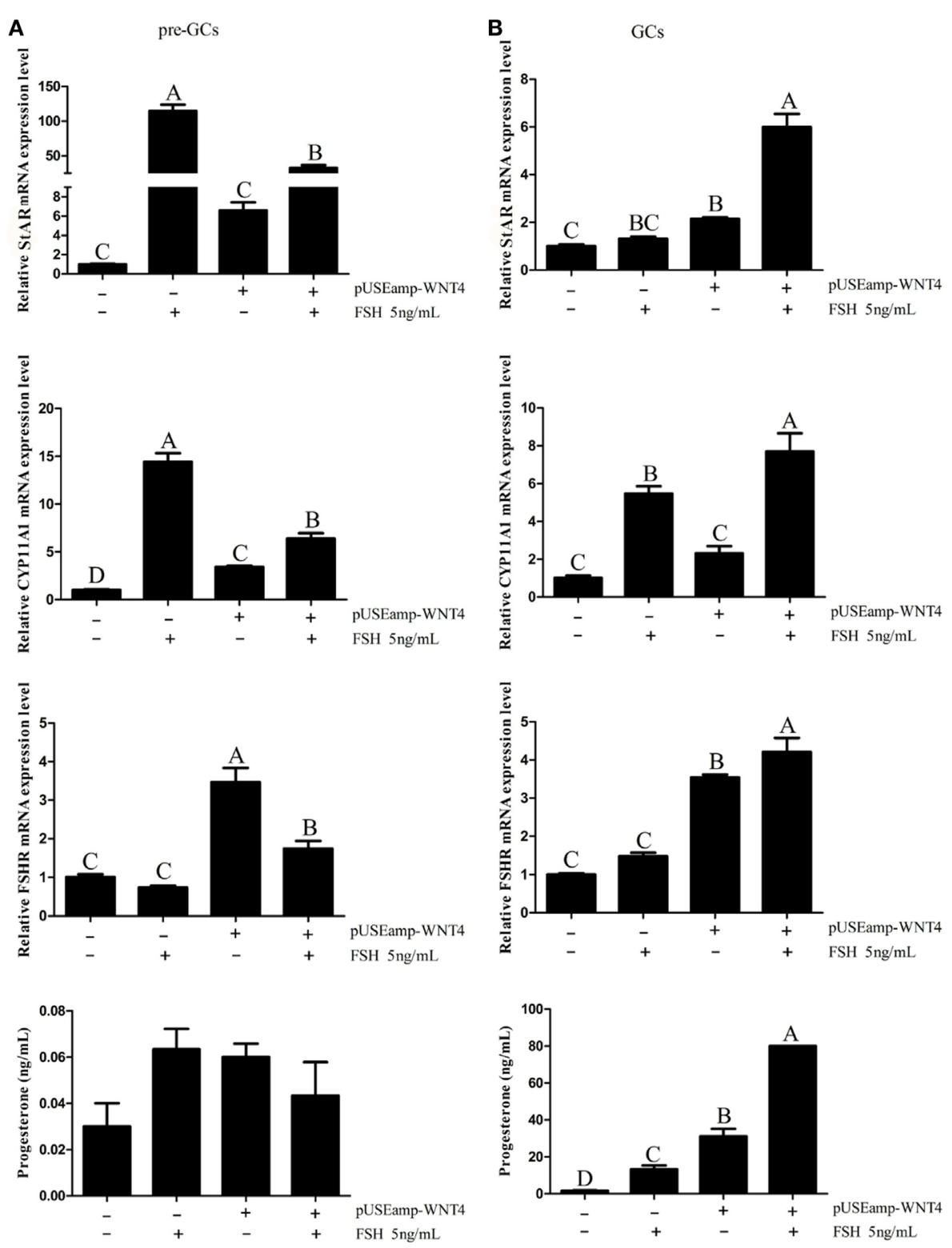

FIGURE 9 | Effects of Wnt4 and follicle-stimulating hormone (FSH) on mRNA expression of steroidogenic enzyme genes and steroidogenesis in prehierarchical and hierarchical follicles. (A) Effects of Wnt4 and FSH on StAR, CYP11A1, and follicle-stimulating hormone receptor (FSHR) mRNA expression and progesterone secretion in the granulosa cells (GCs) of prehierarchical follicles. Bars with different superscript letters are significantly different. (B) Effects of Wnt4 and FSH on StAR, CYP11A1, and FSHR mRNA expression and progesterone secretion in the GCs of hierarchical follicles. $\left({ }^{\mathrm{ABC}} p<0.01\right)$.

yellow follicle is not selected and GCs are not responsive to FSH, the action of FSH is not further strengthened. Similarly, during bovine dominant follicle selection, Wnt signaling was able to potentiate the action of FSH (42). Based on this result, we suppose that during follicle selection, along with the increased expression of FSHR, one small yellow follicle expresses more Wnt4, and the Wnt4 subsequently stimulates the expression of FSHR to enhance the action of FSH signaling, and as such the Wnt4 and FSH pathways act in combination during the development of the follicle from the prehierarchical stage to the hierarchical stage.
In conclusion, transcriptome analysis of single small yellow follicles expressing different levels of FSHR mRNA revealed a role of Wnt4 in chicken follicle selection. The expression of Wnt4 was significantly increased in small yellow follicles, and was higher in GCs than in TCs. Wnt4 could increase the expression of StAR, CYP11A1, and FSHR mRNA in the GCs of prehierarchical and hierarchical follicles and promote GC proliferation. Wnt4 decreased the expression of $A M H$ and OCLN, and its expression was stimulated by FSH. The interaction of Wnt4 and FSH signaling was strengthened from the prehierarchical to hierarchical follicles during the process of follicle selection. This study revealed for 
the first time that Wnt4 stimulates follicle selection by enhancing FSHR expression and GC proliferation and steroidogenesis.

\section{ETHICS STATEMENT}

All of the animal experiments were approved by the Institutional Animal Care and Use Ethics Committee of Shandong Agricultural University and performed in accordance with the "Guidelines for Experimental Animals" of the Ministry of Science and Technology of China.

\section{AUTHOR CONTRIBUTIONS}

YW and YJ contributed to the overall design of the manuscript. YW collected data. QC, ZL, XG, MG, ZY, and YD have contributed by sampling. YW, YJ, YS, and LK have participated in manuscript writing and revision. All authors approved the final version of the manuscript.

\section{ACKNOWLEDGMENTS}

The authors are grateful to Hao Zhang for sample collection.

\section{REFERENCES}

1. Johnson AL. Ovarian follicle selection and granulosa cell differentiation. Poult Sci (2014) 94(4):781-5. doi:10.3382/ps/peu008

2. Johnson AL, Woods DC. Dynamics of avian ovarian follicle development: cellular mechanisms of granulosa cell differentiation. Gen Comp Endocrinol (2009) 163(1-2):12-7. doi:10.1016/j.ygcen.2008.11.012

3. Johnson PA. Follicle selection in the avian ovary. Reprod Domest Anim (2012) 47(Suppl 4):283-7. doi:10.1111/j.1439-0531.2012.02087.x

4. Onagbesan O, Bruggeman V, Decuypere E. Intra-ovarian growth factors regulating ovarian function in avian species: a review. Anim Reprod Sci (2009) 111(2-4):121-40. doi:10.1016/j.anireprosci.2008.09.017

5. Tilly JL, Kowalski KI, Johnson AL. Stage of ovarian follicular development associated with the initiation of steroidogenic competence in avian granulosa cells. Biol Reprod (1991) 44(2):305-14. doi:10.1095/biolreprod44.2.305

6. Johnson AL, Bridgham JT, Witty JP, Tilly JL. Susceptibility of avian ovarian granulosa cells to apoptosis is dependent upon stage of follicle development and is related to endogenous levels of bcl-xlong gene expression. Endocrinology (1996) 137(5):2059-66. doi:10.1210/endo.137.5.8612548

7. Ocón-Grove OM, Poole DH, Johnson AL. Bone morphogenetic protein 6 promotes FSH receptor and anti-Müllerian hormone mRNA expression in granulosa cells from hen prehierarchal follicles. Reproduction (2012) 143:825-33. doi:10.1530/REP-11-0271

8. Kim D, Ocón-Grove O, Johnson AL. Bone morphogenetic protein 4 supports the initial differentiation of hen (Gallus gallus) granulosa cells. Biol Reprod (2013) 88(6):161. doi:10.1095/biolreprod.113.109694

9. Stephens CS, Johnson PA. Bone morphogenetic protein 15 may promote follicle selection in the hen. Gen Comp Endocrinol (2016) 235:170-6. doi:10.1016/j. ygcen.2016.06.027

10. Durlinger AL, Gruijters MJ, Kramer P, Karels B, Kumar TR, Matzuk MM, et al. Anti-Mullerian hormone attenuates the effects of FSH on follicle development in the mouse ovary. Endocrinology (2001) 142:4891-9. doi:10.1210/ endo.142.11.8486

11. Johnson PA, Kent TR, Urick ME, Giles JR. Expression and regulation of anti-Mullerian hormone in an oviparous species, the hen. Biol Reprod (2008) 78:13-9. doi:10.1095/biolreprod.107.061879

12. Schuster MK, Schmierer B, Shkumatava A, Kuchler K. Activin A and follicle-stimulating hormone control tight junctions in avian granulosa cells by

\section{FUNDING}

This work was funded by the National Natural Science Foundation of China (NSFC 31672414, 31272435) and the Funds of Shandong "Double Tops" Program (SYL2017YSTD12).

\section{SUPPLEMENTARY MATERIAL}

The Supplementary Material for this article can be found online at http://www.frontiersin.org/article/10.3389/fendo.2017.00317/ full\#supplementary-material.

TABLE S1 | Primers used in this study (DOCX).

TABLE S2 | The target sequences of shRNA expression vectors (DOCX).

TABLE S3 | Raw data of RNA-seq analysis (XLSX).

TABLE S4 | The differentially expressed genes in six follicles (XLSX).

TABLE S5 | Genes involved in protein-protein interaction network analysis (XLSX).

TABLE S6 | KEGG pathways of differentially expressed genes (XLSX).

TABLE S7 | Gene ontological classification of differentially expressed genes (XLSX).

regulating occludin expression. Biol Reprod (2004) 70:1493-9. doi:10.1095/ biolreprod.103.024331

13. Johnson AL, Solovieva EV, Bridgham JT. Relationship between steroidogenic acute regulatory protein expression and progesterone production in hen granulosa cells during follicle development. Biol Reprod (2002) 67(4):1313. doi:10.1095/biolreprod67.4.1313

14. Woods D, Johnson AL. Regulation of follicle-stimulating hormone-receptor messenger RNA in hen granulosa cells relative to follicle selection. Biol Reprod (2005) 72:643-50. doi:10.1095/biolreprod.104.033902

15. Lustig B, Behrens J. The Wnt signaling pathway and its role in tumor development. J Cancer Res Clin Oncol (2003) 129(4):199-221. doi:10.1007/ s00432-003-0431-0

16. Logan CY, Nusse R. The Wnt signaling pathway in development and disease. Annu Rev Cell Dev Biol (2004) 20:781-810. doi:10.1146/annurev. cellbio.20.010403.113126

17. Anastas JN, Moon RT. Wnt signalling pathways as therapeutic targets in cancer. Nat Rev Cancer (2013) 13:11-26. doi:10.1038/nrc3419

18. Komiya Y, Habas R. Wnt signal transduction pathways. Organogenesis (2008) 4(2):68-75. doi:10.4161/org.4.2.5851

19. Niehrs C. The complex world of WNT receptor signaling. Nat Rev Mol Cell Biol (2012) 13:767-79. doi:10.1038/nrm3470

20. Boyer A, Lapointe E, Zheng XF, Cowan RG, Li HG, Quirk SM, et al. WNT4 is required for normal ovarian follicle development and female fertility. FASEB J (2010) 24(8):3010-25. doi:10.1096/fj.09-145789

21. Hsieh M, Johnson MA, Greenberg NM, Richards JS. Regulated expression of Wnts and Frizzleds at specific stages of follicular development in the rodent ovary. Endocrinology (2002) 143:898-908. doi:10.1210/endo.143. 3.8684

22. Yao HH, Matzuk MM, Jorgez CJ, Menke DB, Page DC, Swain A, et al. Follistatin operates downstream of Wnt 4 in mammalian ovary organogenesis. Dev Dyn (2004) 230(2):210-5. doi:10.1002/dvdy.20042

23. Lim CH, Lim W, Jeong W, Lee JY, Bae SM, Kim J, et al. Avian WNT4 in the female reproductive tracts: potential role of oviduct development and ovarian carcinogenesis. PLoS One (2013) 8(7):e65935. doi:10.1371/journal. pone.0065935

24. Livak KJ, Schmittgen TD. Analysis of relative gene expression data using realtime quantitative PCR and the $2^{-\Delta \Delta \mathrm{CT}}$ method. Methods (2001) 25(4):402-8. doi:10.1006/meth.2001.1262 
25. Webb R, Nicholas B, Gong JG, Campbell BK, Gutierrez CG, Garverick HA, et al. Mechanisms regulating follicular development and selection of the dominant follicle. Reprod Suppl (2003) 61(2):71-90.

26. Johnson PA, Stephens CS, Giles JR. The domestic chicken: causes and consequences of an egg a day. Poult Sci (2015) 94:816-20. doi:10.3382/ps/peu083

27. Johnson AL, Lee J. Granulosa cell responsiveness to follicle stimulating hormone during early growth of hen ovarian follicles. Poult Sci (2016) 95:108-14. doi:10.3382/ps/pev318

28. Zhu G, Yong M, Zhou W, Jiang Y. Dynamic changes in the follicular transcriptome and promoter DNA methylation pattern of steroidogenic genes in chicken follicles throughout the ovulation cycle. PLoS One (2015) 10(12):e0146028. doi:10.1371/journal.pone.0146028

29. Li L, Ji SY, Yang JL, Li XX, Zhang J, Zhang Y, et al. Wnt/ $\beta$-catenin signaling regulates follicular development by modulating the expression of Foxo3a signaling components. Mol Cell Endocrinol (2014) 382(2):915-25. doi:10.1016/j. mce.2013.11.007

30. Stapp AD, Gomez BI, Gifford CA, Hallford DM, Hernandez Gifford JA. Canonical WNT signaling inhibits follicle stimulating hormone mediated steroidogenesis in primary cultures of rat granulosa cells. PLoS One (2014) 9:e86432. doi:10.1371/journal.pone.0086432

31. Diaz FJ, Anthony K, Halfhill AN. Early avian follicular development is characterized by changes in transcripts involved in steroidogenesis, paracrine signaling and transcription. Mol Reprod Dev (2011) 78(3):212-23. doi:10.1002/ $\operatorname{mrd} .21288$

32. Vainio S, Heikkila M, Kispert A, Chin N, McMahon AP. Female development in mammals is regulated by Wnt-4 signalling. Nature (1999) 397:405-9. doi:10.1038/17068

33. Hsieh M, Mulders SM, Friis RR, Dharmarajan A, Richards JS. Expression and localization of secreted frizzled-related protein- 4 in the rodent ovary: evidence for selective up-regulation in luteinized granulosa cells. Endocrinology (2003) 144(10):4597-606. doi:10.1210/en.2003-0048

34. Harwood BN, Cross SK, Radford EE, Haac BE, De Vries WN. Members of the WNT signaling pathways are widely expressed in mouse ovaries, oocytes, and cleavage stage embryos. Dev Dyn (2008) 237(4):1099-111. doi:10.1002/ dvdy.21491

35. Sanchez AM, Vigano P, Quattrone F, Pagliardini L, Papaleo E, Candiani M, et al. The WNT/ $\beta$-catenin signaling pathway and expression of survival promoting genes in luteinized granulosa cells: endometriosis as a paradigm for a dysregulated apoptosis pathway. Fertil Steril (2014) 101(6):1688-96. doi:10.1016/j.fertnstert.2014.02.040
36. Jaaskelainen M, Prunskaite-Hyyrylainen R, Naillat F, Parviainen $H$, Anttonen M, Heikinheimo M, et al. WNT4 is expressed in human fetal and adult ovaries and its signaling contributes to ovarian cell survival. Mol Cell Endocrinol (2010) 317(1-2):106-11. doi:10.1016/j.mce.2009.11.013

37. You S, Bridgham JT, Foster DN, Johnson AL. Characterization of the chicken follicle-stimulating hormone receptor ( $\mathrm{CFSH}-\mathrm{R}$ ) complementary deoxyribonucleic acid, and expression of cFSH-R messenger ribonucleic acid in the ovary. Biol Reprod (1996) 55(5):1055-62. doi:10.1095/biolreprod55.5.1055

38. Castanon BI, Stapp AD, Gifford CA, Spicer LJ, Hallford DM, Hernandez Gifford JA. Follicle-stimulating hormone regulation of estradiol production: possible involvement of WNT2 and beta-catenin in bovine granulosa cells. J Anim Sci (2012) 90:3789-97. doi:10.2527/jas.2011-4696

39. Fan HY, O'Connor A, Shitanaka M, Shimada M, Liu Z, Richards JS. $\beta$-Catenin (CTNNB1) promotes preovulatory follicular development but represses LH-mediated ovulation and luteinization. Mol Endocrinol (2010) 24(8):1529-42. doi:10.1210/me.2010-0141

40. Parakh TN, Hernandez JA, Grammer JC, Weck J, Hunzicker-Dunn M, Zeleznik AJ, et al. Follicle-stimulating hormone/cAMP regulation of aromatase gene expression requires $\beta$-catenin. Proc Natl Acad Sci U S A (2006) 103(33):12435-40. doi:10.1073/pnas.0603006103

41. CastañoBI,Stapp AD, GiffordCA,SpicerLJ,HallfordDM,HernandezGiffordJA. Follicle-stimulating hormone regulation of estradiol production: possible involvement of WNT2 and $\beta$-catenin in bovine granulosa cells. J Anim Sci (2012) 90(11):3789-97. doi:10.2527/jas.2011-4696

42. Gupta PSP, Folger JK, Rajput SK, Lv L, Yao J, Ireland JJ, et al. Regulation and regulatory role of WNT signaling in potentiating FSH action during bovine dominant follicle selection. PLoS One (2014) 9(6):e100201. doi:10.1371/ journal.pone.0100201

Conflict of Interest Statement: The authors declare that the research was conducted in the absence of any commercial or financial relationships that could be construed as a potential conflict of interest.

Copyright (c) 2017 Wang, Chen, Liu, Guo, Du, Yuan, Guo, Kang, Sun and Jiang. This is an open-access article distributed under the terms of the Creative Commons Attribution License (CC BY). The use, distribution or reproduction in other forums is permitted, provided the original author(s) or licensor are credited and that the original publication in this journal is cited, in accordance with accepted academic practice. No use, distribution or reproduction is permitted which does not comply with these terms. 